\title{
JJBF FRENCH BANKS AMID THE GLOBAL FINANCIAL CRISIS
}

\author{
Yingbin Xiao \\ International Monetary Fund USA
}

\begin{abstract}
This paper runs the gamut of qualitative and quantitative analyses to examine the performance of French banks during 2006-2008 and the financial support measures taken by the French government. French banks were not immune but proved relatively resilient to the global financial crisis reflecting their business and supervisory features. An event study of the impact of government measures on CDS, debt, and equity markets points to the reduction of credit risk and financing cost as well as the redistribution of resources. With the crisis still unfolding, uncertainties remain and challenges lie ahead, calling for continued vigilance and enhanced risk management.
\end{abstract}

Keywords: French banks, Financial crisis, Recapitalization, Debt guarantee, Government support, Refinancing

JEL Classification: G01, G12, G15, G21, G28

\section{Introduction}

The ongoing global financial crisis has posed great challenges to financial systems and governments to manage the economies around the globe. That is also the case in France. The unprecedented nature of the crisis and government bailouts highlight the importance of having a sound system and an appropriate policy response. It also points to the value of having a good grasp of the financial sector performance and government support measures of systemic importance.

This paper attempts to analyze the performance of French banks and the financial support measures taken by the French government. France has a large and sophisticated financial system, which accounts for ten percent of the global banking system and five percent of the global capital markets. Besides, it hosts the second largest mutual fund industry. The impact of the crisis on the French financial system, especially on the banks, and the policies adopted after the crisis matter for the global economy and financial stability.

The rest of the paper is organized as follows. Section 2 presents an overview of the French banking and supervision structure. Section 3 conducts international comparative analyses of profitability, asset quality, capital 
adequacy, leverage, quality of capital, funding profile, and liquidity of banks. Section 4 analyses business lines, potential spillovers, writedowns and losses, new capital raised, and market perceptions of risk. Section 5 analyses the government support plan of banks and carries out an event study of the market impact of the measures. Section 6 concludes.

\section{Banking and Supervisory Structure}

The French banking system features a small number of large universal banks spanning a wide range of business functions. The banks are largely organized along commercial, mutual, and cooperative lines. Private commercial banks dominate the system with an asset value of about five times that of mutual and cooperative banks. The close ties among banks, life insurance companies, and asset management companies, sometimes underpinned by cross-shareholding, tend to blur divisions among different types of institutions.

The French banking sector is an integral part of the European and international banking system. Home banks' external claims well exceed host banks' external claims. Foreign banks have made few inroads into the French mainstream banking, the exception being the HSBC. Although domestic banks dominate retail banking, the foreign banks are free to compete and have gained a strong market presence in wholesale banking and securities trading. However, cross border mergers and acquisitions may blur the line between domestic and foreign banks as leading French banks become partly foreign owned, as in the case of the Belgian government's ownership of BNP Paribas after its recent acquisition of Fortis bank.

French banking is highly consolidated. The nine largest banks account for 75 percent of the total banking assets. The top five banks represent half of the total deposits and more than a half of the total lending. Banking concentration has largely stabilized over the last three years, but will rise with the merger between Groupe Caisse d'Épargne (GCE) and Groupe Banque Populaire (GBP) this year.

The financial supervision structure is based on a functional approach with some twin peaks elements. The oversight of financial services was reformed in 2003 with a view to enhancing regulatory efficiency. Hence, the financial supervisory framework was reorganized and substantially simplified. The Monetary and Financial Code does not distinguish between commercial banks and investment banks. The prudential supervision of both banks and investment firms falls under the Commission Bancaire (CB), which ensures consistent coverage of all credit institutions. The proximity between the Banque de France $(\mathrm{BdF})$ and $\mathrm{CB}$ facilitates timely information-sharing as the Governor of the BdF serves as the chairman of the $\mathrm{CB}$, and $\mathrm{BdF}$ provides budget, human resources, and other support to the $\mathrm{CB}$. The board of financial sector authorities offers a domestic coordination framework. 
Xiao: French Banks

\section{International Comparative Analyses}

The analyses employ selected soundness indicators of French banks and comparisons during 2006-08. The study period covers the pre-crisis period, the beginning, and the middle of the global financial crisis. Given the financial integration and the global nature of the French banking business, a bank-based, rather than a country-based, comparison group is constructed. It consists of 48 large banks in advanced Europe. To ensure comparability, only banks adopting the International Financial Reporting System (IFRS) are included. Bank data are from Bankscope and Thomson Financial. Composite indicators weighted by size for the comparison group and nine major French banks respectively are constructed to facilitate aggregate comparisons.

Selected soundness indicators focus on bank profitability, asset quality, capital adequacy, leverage, capital quality, funding profile, and liquidity. Profitability is measured by operating income on average assets (ROAA) and return on average equity (ROAE), gauging both the operating performance and the bottom line. Asset quality is measured by the non-performing loans (NPL) ratio and coverage ratio, gauging NPL and the sufficiency of provisions, respectively. Capital adequacy is measured by the Tier I ratio, a widely used regulatory indicator. Leverage is defined as assets over shareholders' equity. Capital quality is measured by the share of Tier II capital in total capital and the core Tier 1 ratio in view of investors' recent focus. The banks' funding profile is measured by the share of wholesale funding in total funding and the share of short-term wholesale funding in short-term funding, gauging the banks' dependence on capital market funding. Liquidity is measured by the depositto-loan ratio and liquid ratio defined by liquid assets over liquid liabilities, examining liquidity from an asset-liability management (ALM) perspective.

\subsection{Profitability}

French banks were less profitable than their European peers before the crisis, but were affected less hard by the crisis. The operating ROAA and ROAE were below those of the peers in 2006, reflecting narrower interest margins and less exposure to profitable, but risky non-traditional banking activities. With intense competition among banks, the net interest margin of French banks eroded to a level below their peers. Both French banks and their European peers registered plummeting operating performance and net income in 2008, with the profitability of European banks turning negative while that of French banks overall remained slightly positive. This is largely due to the fact that the majority of French banks still earned modest profits in 2008: See Figure 1.

\subsection{Asset Quality}

Figure 2 provides information on this aspect. The quality of French banks' loan portfolios was almost on par with that of their European peers, but the fall of provisions was less pronounced during the crisis. Both French banks and their 
European peers saw a declining NPL ratio in 2007, but a reversal was evident in 2008, reflecting the turn of the economic and credit cycle, as well as the ensuing rise in defaults. The coverage ratio of both the French banks and the European peers dropped appreciably in 2008, suggesting less provision to cover more problem loans. French banks had less coverage than their European peers initially, but with a less marked deterioration ended up with a higher coverage ratio in 2007-08.

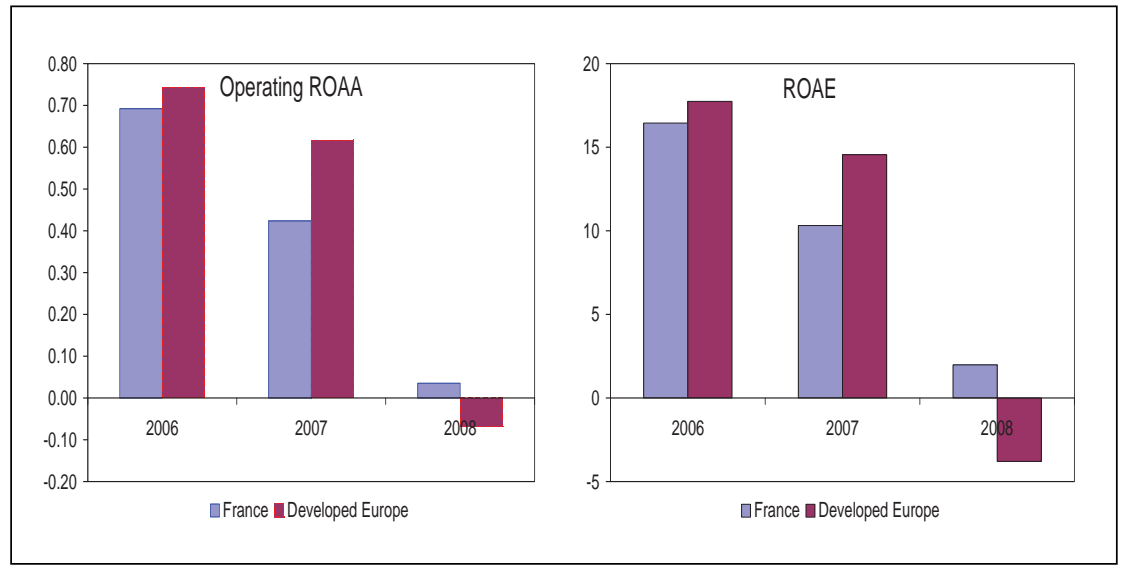

Figure 1: Operating performance of French vs European banks

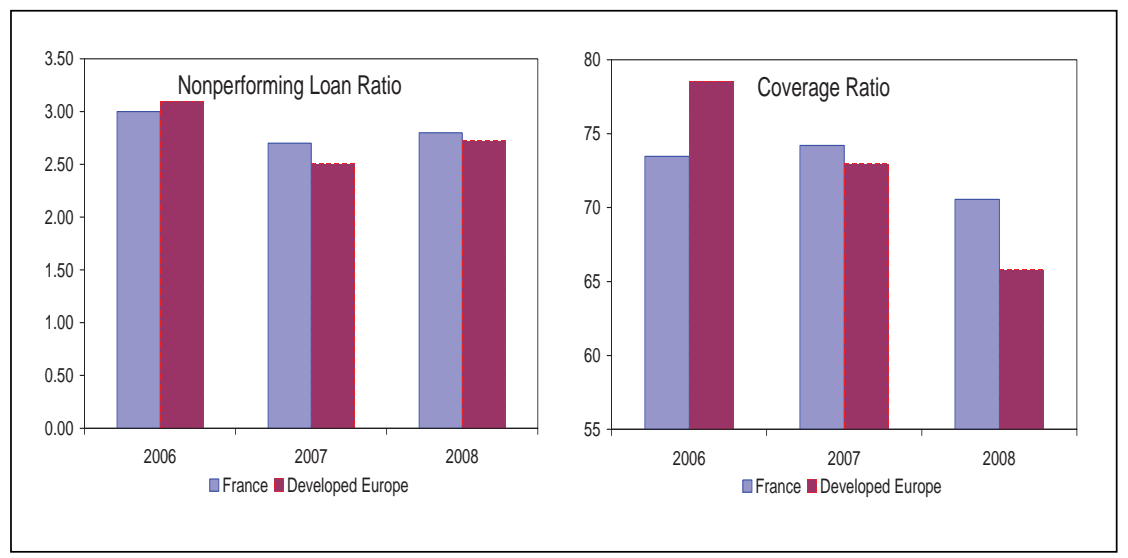

Figure 2: Asset quality of French vs European Banks

\subsection{Capital Adequacy}

As is evident from the information in Figure 3, regulatory capital adequacy of French banks was stronger than that of their European peers before the crisis, but gradually lost its relative strength: see Figure 3. In 2006, the Tier I ratio of French 
banks was about 100 basis points above that of their peers. The outbreak of the crisis in 2007 eroded the buffers for both the French banks and their European peers. With massive government recapitalization efforts in some countries in 2008, the edge of the capital positions of the French banks shrank and converged with the others.

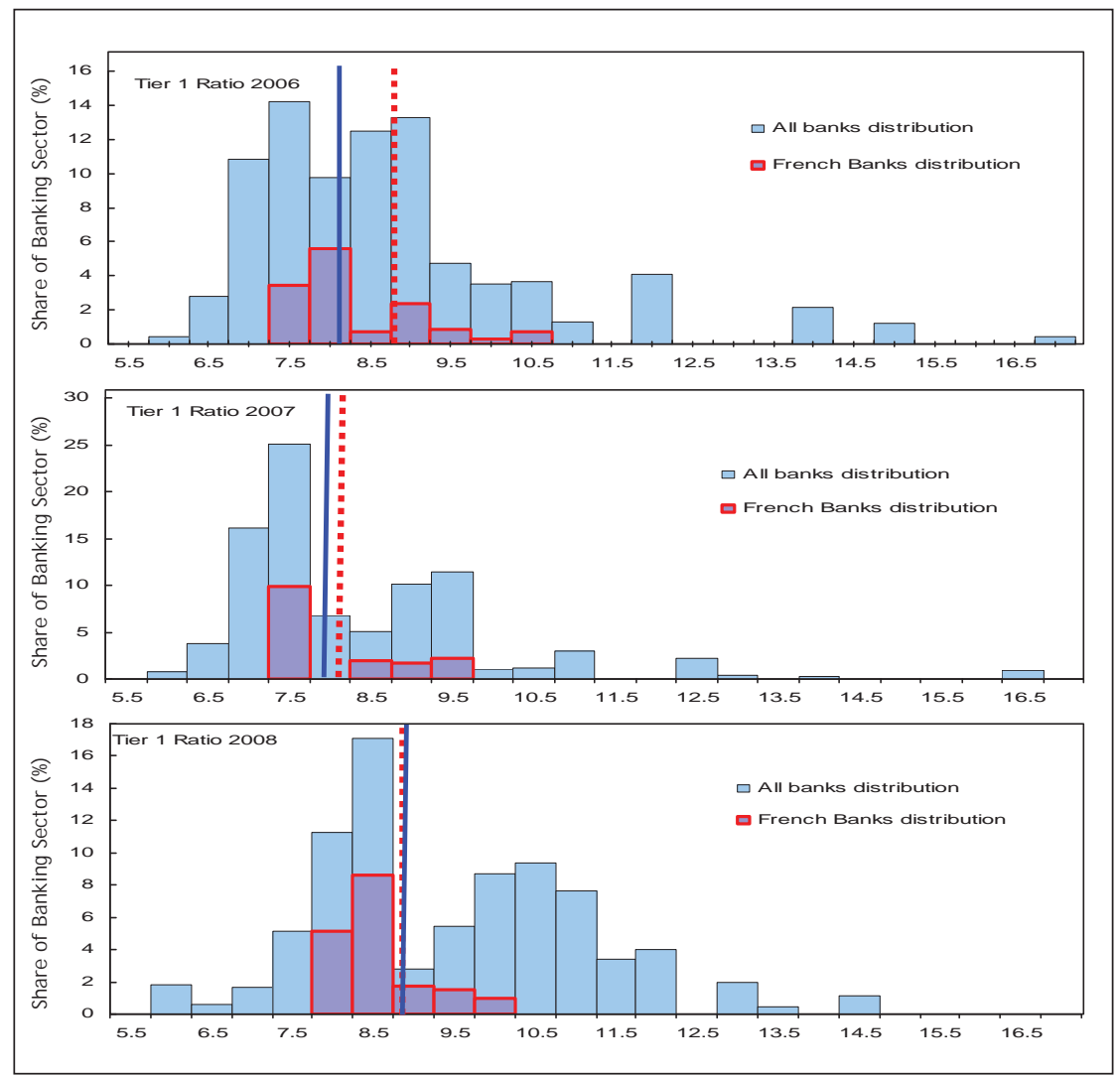

Figure 3: Capital adequacy of French vs European banks

\subsection{Leverage}

The level and evolution of the leverage of French banks mirrored those of their European peers: see Figure 4. Both groups showed no signs of deleveraging from their pre-crisis levels, an interesting phenomenon that contradicts the conventional perception that banks would be forced or inclined to reduce leverage because of the crisis. The annual report of 2008 noted that the banks continued to expand their intermediation business, although at a slower pace. The report examined leverage as measured by the ratio of loan volume over equity and loan volume weighted by asset quality over equity. It concluded that 
leverage stabilized and French banks did not appear to choose an aggressive strategy of reducing outstanding loans or restricting the distribution of riskier loans.

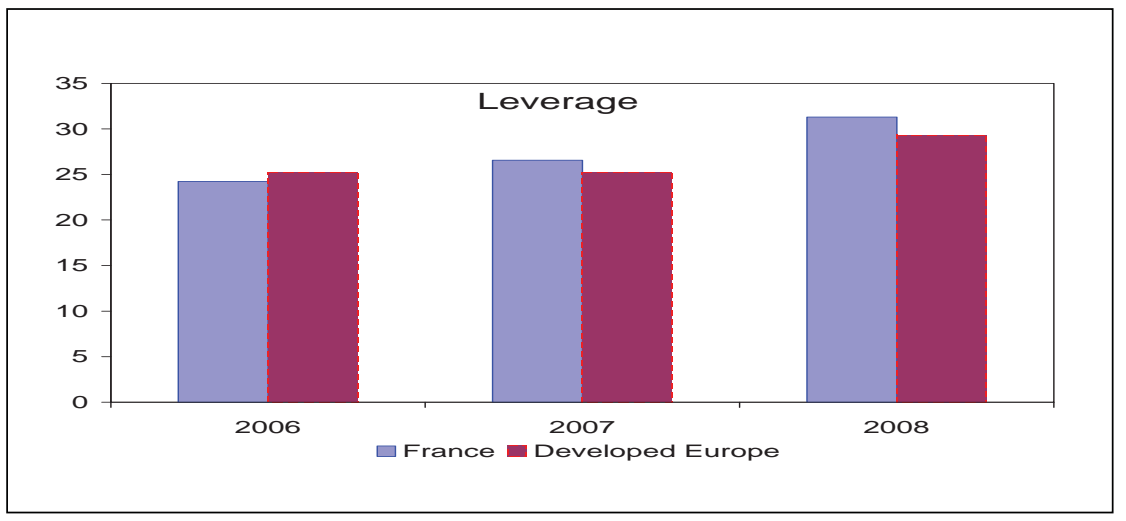

Figure 4: Leverage of French vs European banks

\subsection{Quality of Capital}

Information on quality of capital is provided in Figure 5. The crisis has sparked intense discussions about the quality of capital, the significance of which is highlighted in supervisory guidelines. For example, the Basel Committee Banking Supervision (BCBS) Guidelines noted that core Tier 1 capital should be a predominant part of Tier 1. The Turner Review pointed out that "The FSA therefore believes that required capital ratios for such banks should be expressed entirely in terms of high quality capital—broadly speaking the current Core Tier 1 and Tier 1 definitions-and should not count dated subordinated debt as providing relevant support. This is in line with the direction of the Basel Committee deliberations." The US Supervisory Capital Assessment Program (SCAP) argued that "Supervisors have long indicated that common equity should be the dominant component of Tier 1 capital....".

French banks had a higher capital quality initially, but their lead was eroded following the raft of global recapitalizations across the industry: see Figure 5. Both the French banks and their European peers increased the share of Tier II capital in the capital structure in 2008, although the increase was somewhat smaller for French banks. With investors putting less emphasis on Tier II capital, several European banks, including some French banks, have considered or conducted liability management operations to buy back their lower Tier II capital to improve the quantity and quality of capital. The core Tier I ratio of French banks was about 15 basis points above that of others in 2007, and stood on par with their peers after the wave of government recapitalizations in 2008 . 

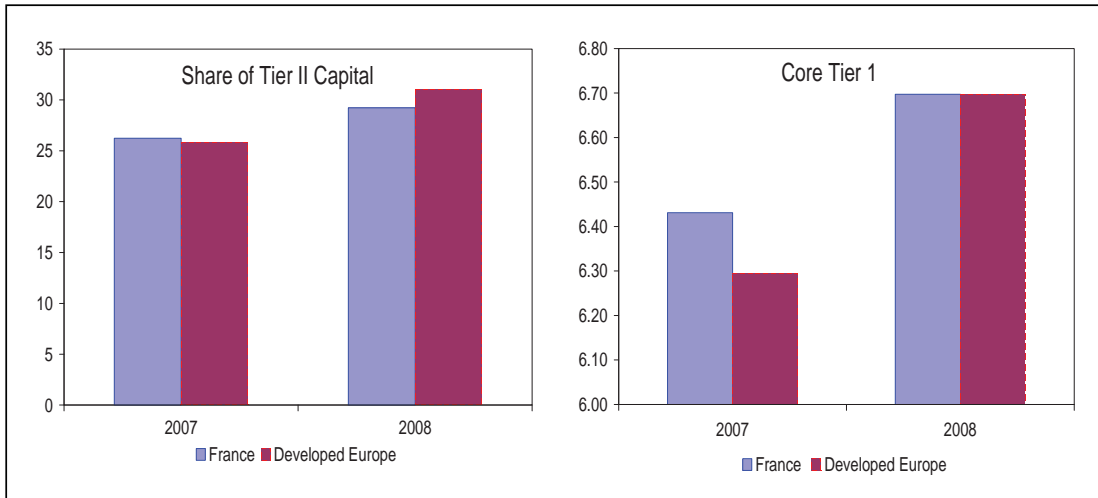

Figure 5: Capital quality of French vs European banks

\subsection{Funding}

French banks appear to have a rising and higher-than-average reliance on wholesale funding: Figure 6. A bank's funding strategy at different maturities tends to affect the banks' fragility and its sensitivity to a liquidity dry-up. Deposit funding and wholesale funding may carry different risks in causing a potential liquidity crisis and bringing about changes in funding costs. French banks have increased their recourse to wholesale funding with the rapid expansion of their activities and a shift to high-fee generating products for funding. An examination of French banks' average funding profile during 2006-08 reveals that wholesale funding represents 58 percent of the total funding and short-term (ST) wholesale funding accounts for about 35 percent of ST funding in the case of French banks, but 47 percent and 28 percent, respectively, in the case of their European peers. Though at first appearance it seems at odds with the high savings ratio of France, this reflects the role of the money market funds and life insurance products in diversified bank funding.

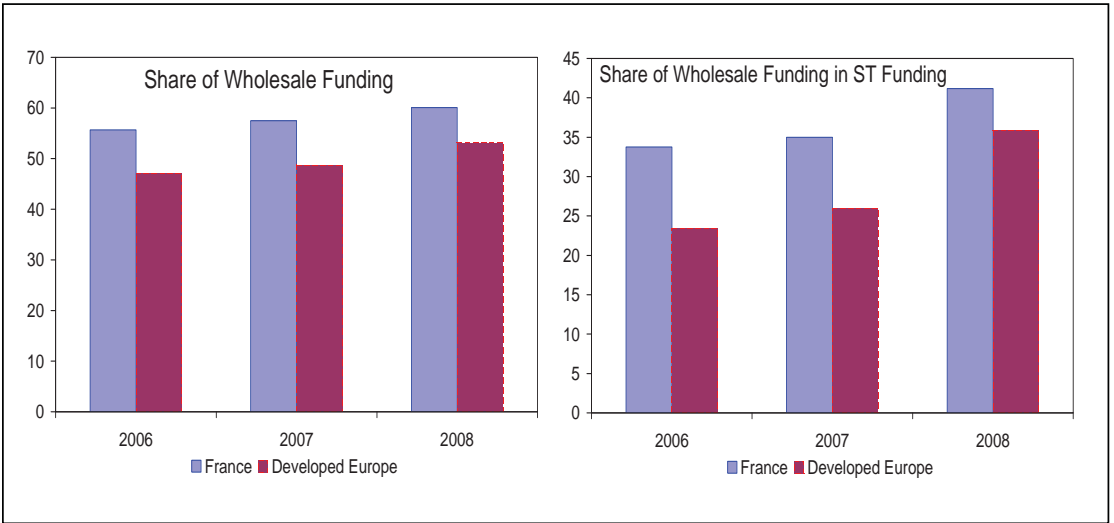

Figure 6: Funding of French vs European banks 
The liquidity profile of the French banks as seen in Figure 7 from the ALM perspective appears to be slightly more favourable than that of their European peers, although this is becoming less over time. While the funding profile focuses on the liability side, the ALM perspective focuses on liquidity matching from both assets and liabilities. The deposit-to-loan ratio shows the extent to which domestic credit is funded by banks' deposit liabilities. Any shortfall, as reflected in a ratio of less than 100 percent, has to be funded by bank borrowing from the non-bank private sector or from overseas, both of which have become constrained in the crisis. Banks with a high coverage ratio of customer loans by deposits are less vulnerable and more resilient in the face of increased tension in liquidity markets. The deposit-to-loan ratio of French banks rose to 75 percent in 2007, but slid in 2008, although it still remained above the level of the European peers. The liquid ratio of French banks declined by half to reach a similar level as their peers in 2008. However, the liquidity profiles of French banks may improve with the generalization of Livret A and Livret Bleu (special saving accounts in France) at the beginning of 2009, which has encouraged banks to attract more deposits.

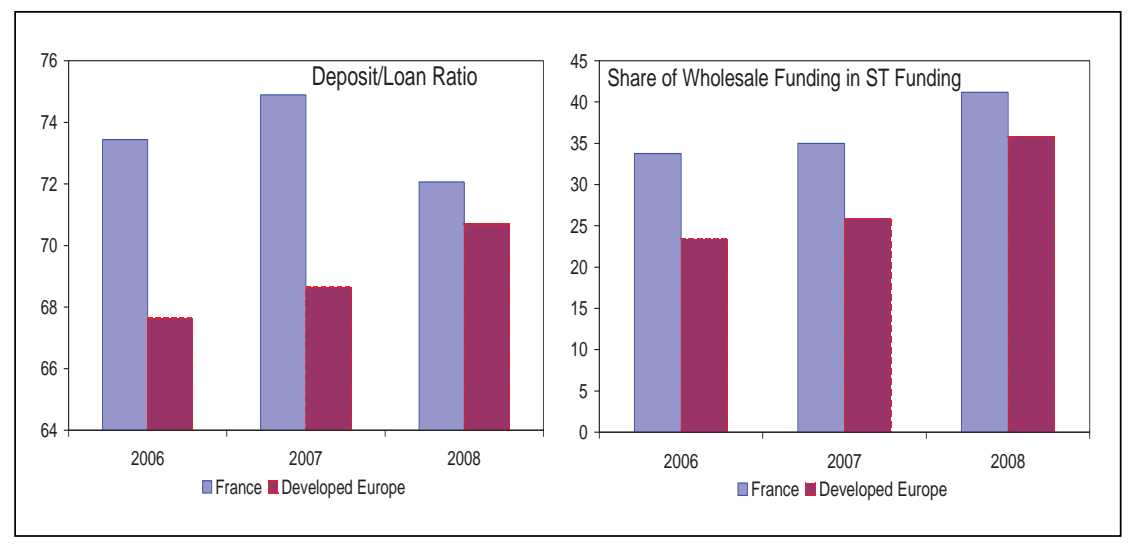

Figure 7: Liquidity measures of French vs European banks

\section{Analyses of Business and Exposures}

The analyses of business and exposures supplement the above soundness check to gain more insights about the relative performance of French banks. Specifically, this section analyses business lines, international exposures, writedowns and losses, new capital raised, and market perceptions of risk. Financial data come from Bloomberg, the BIS, Datastream, Thomson Financial, and the financial statements of banks.

Domestic and international retail banking activities contributed to the financial results of French banks. French banks have adopted a domestic retaildominated universal banking model. An analysis of the business lines shows that 
retail banking activities, especially international banking, continued their brisk growth throughout the crisis. The share of domestic business climbed modestly to 46 percent, reflecting the low risk and high saturation of domestic markets. The contribution of international banking to operating income rose significantly from 18 percent in 2006 to 27 percent in 2008, reflecting the French banks' geographic diversification and brisk expansion to fast-growing countries.

However, corporate and investment banking (CIB) and asset management activities detracted from the financial strength of the French banks. CIB business, the key profit driver in the past, was hit hardest by the crisis. Its contribution to operating income fell from the pre-crisis level of 24 percent to 10 percent in 2008, reflecting plummeting revenues and even sizable losses for some banks. They suffered from impairment charges and fair value losses from toxic assets including sub-prime related residential mortgage-backed securities (RMBS), collaterized debt obligations (CDO), asset-backed securities (ABS), and exposures to monoline and credit derivative product companies (CDPC). Increased risk aversion shunned investors away from complex CIB products and services, which materially compressed CIB revenues and depressed its profitability. The economic downturn and market volatility also weighed on other structured products such as commercial mortgage-backed securities (CMBS), leveraged buy-outs (LBO), collaterized loan obligations (CLO) as well as trading and advisory services. Significant outflows arising from volatility, a loss of confidence associated with a "breaking of the buck" in the U.S. moneymarket funds, problems with the "dynamic" money market funds, and poor performances of hedge funds dealt a blow to profits from asset management activities, although to a lesser degree than for CIB activities. With the partly offsetting income from private banking, the contribution from the combined asset management and private banking (AM \& PB) fell back to its pre-crisis level.

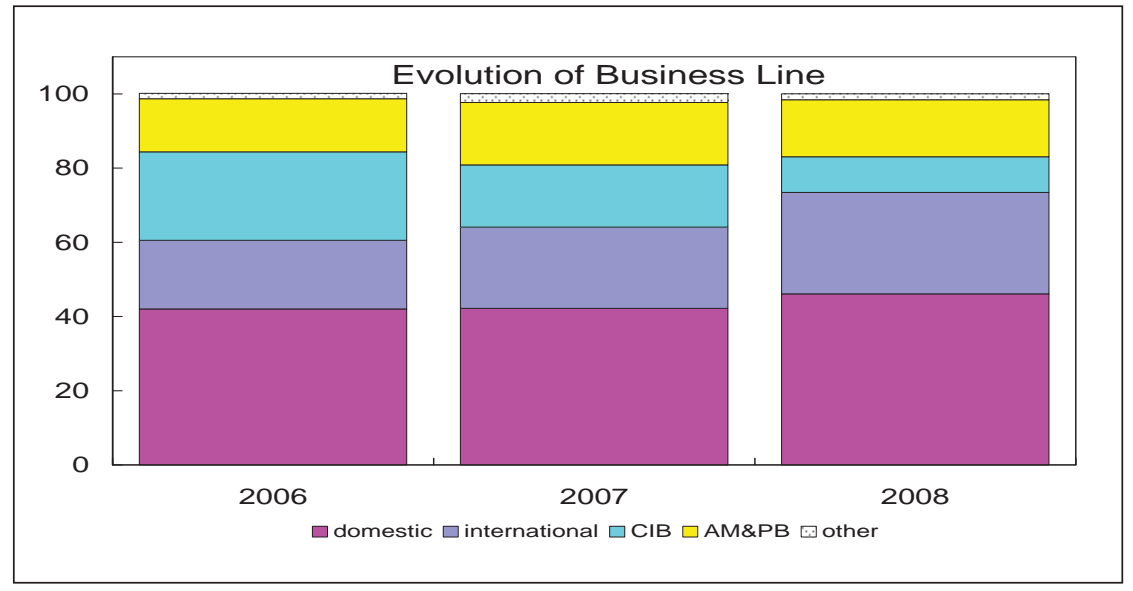

Figure 8: Business lines of French banks 
The French banks' exposure to foreign markets is not excessive and tilts towards mature markets. Foreign claims on an immediate borrower basis represented 34 of bank assets and 128 percent of GDP at the end of 2008 while foreign claims on an ultimate risk basis were slightly lower. The exposure in terms of the size of the national economy aligns with countries such as Austria, Germany, Sweden, and the U.K. and lies between the very low level of the U.S. and the very high level of Switzerland. Banks' exposure to mature market dominates, representing 86 percent of total foreign claims. Exposure to the U.S., Italy, the U.K., and Germany accounts for more than half of the total exposure to mature markets. The mature market bias suggests that potential spillovers from these markets may have a material impact on French banks.

The French banks' exposure to offshore financial centers and emerging markets is limited. Exposure to emerging markets on either an immediate borrower basis or an ultimate risk basis represented about four percent of bank assets and 14 percent of GDP at the end of 2008, only higher than the U.S. and the U.K. Exposure to offshore financial centers is even smaller: see Figure 9.

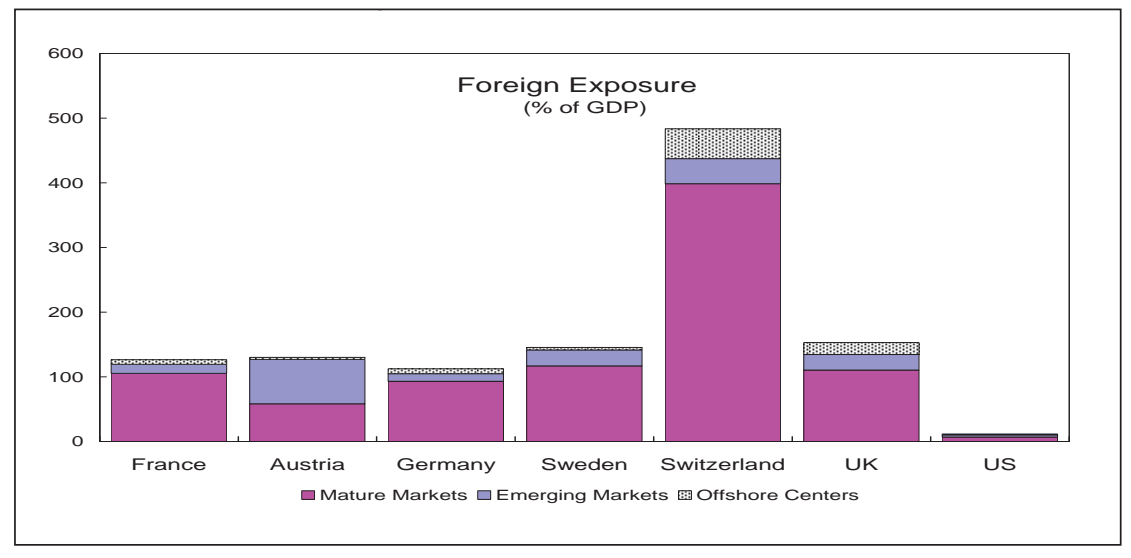

Figure 9: Foreign exposure of French banks

The exposure to emerging markets is geographically diversified. Exposure to Central and Eastern Europe (CEE) made up about 36 percent of the total exposure to emerging markets, followed by Africa and the Middle East (28 percent), and Asia and the Pacific (24 percent) at the end of 2008. Among the exposure to CEE, exposure to the Czech Republic, Russia, and Poland accounts for half of the total exposure. Among the three major French banks having exposure to CEE, only one bank has a sizable exposure. Although pressure on French banks could be mounting with a worsening of the financial situation in the CEE region or emerging markets in general, the overall risks may be manageable: Figure 10. 


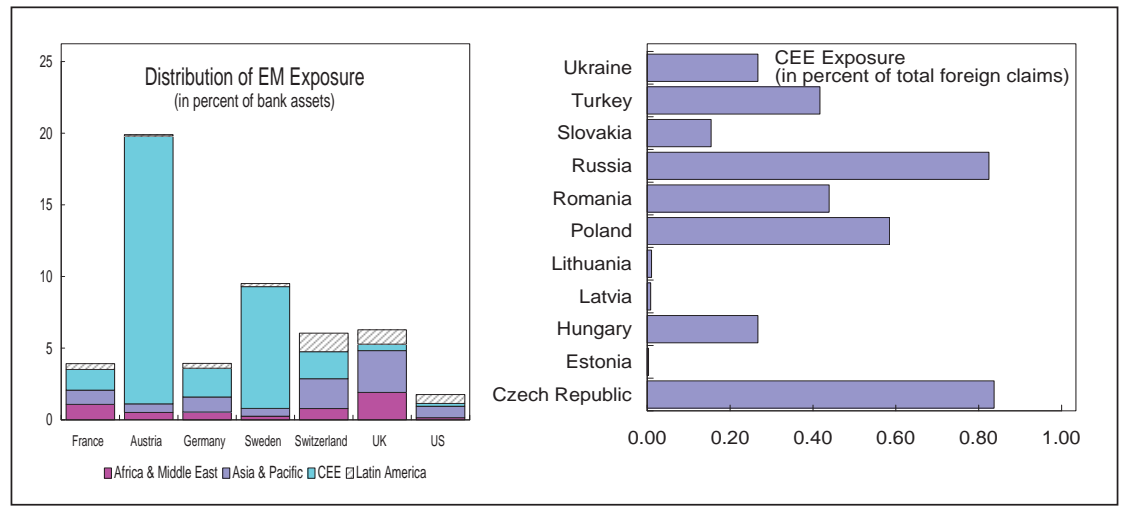

Figure 10: Emerging market exposure of French banks

Losses and writedowns of French banks have been significant, but comparatively less than in the hardest-hit countries: see Figure 11. French banks have written down a large proportion of assets relative to their initial value. Their total losses and write-downs since the onset of the crisis account for about 3 percent of losses and write-downs around the globe, considerably less than those of banks in the U.S. (55 percent), the U.K. (12 percent), Germany (9 percent), and Switzerland (7 percent), and also less than the share of French banks in the global banking system. The international comparison of the CB on the direct cost of the crisis for large international banks shows that the direct cost for the French banks was about 18 percent of Tier 1 capital, lower than that of Germany (about 33 percent), the U.K. (about 37 percent), the U.S. (about 86 percent), and Switzerland (about 87 percent). ${ }^{1}$

Recapitalization has been able to cover the losses and write-downs already incurred. French banks have made progress in shoring up their balance sheets by attracting capital from financial markets and accepting government capital injections. State capital injections represent about one-third of new capital and play an increasing important role over time. Total capital raised by French banks accounts for about 4 percent of the aggregate capital raised around the globe, roughly equal to their share of losses and write-downs.

The market perception of credit risk of French banks seems to be more favorable than that of their European peers, especially for the lower class of debt. Reflecting rising credit risk, credit default swaps (CDS) spreads of French banks and other European banks have increased considerably. In the case of senior CDS spreads of French banks, spreads have shot up from less than 10 basis points before the crisis to more than 100 basis points recently. Throughout most of the crisis period, senior CDS spreads of French banks have been lower than those of peers, as measured by the iTraxx Euro Senior CDS index. In the case of junior CDS spreads of French banks, spreads have surged from less than 30 basis points before the crisis to more than 150 basis points recently. As in the

${ }^{1}$ For details, see Commission bancaire (2009). 
case of senior CDS spreads, throughout most of the crisis period, junior CDS spreads of French banks have been lower than those of peers measured by the iTraxx Euro Junior CDS index. Moreover, the difference is more striking. For example, junior CDS spreads of French banks were 36 percent below those of the iTraxx Euro Junior CDS index at the peak of the crisis in March 2009 and 24 percent lower in June.

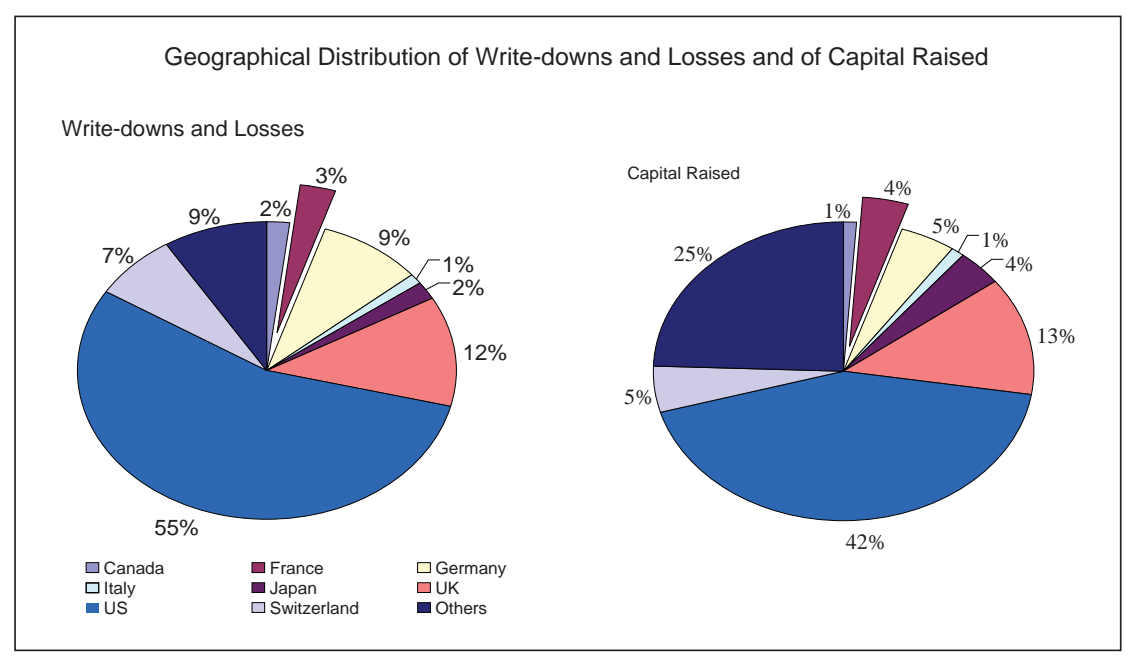

Figure 11: Write-downs, losses and capital raised by French banks

Senior CDS spreads of French banks were 17 percent and 8 percent below those of the iTraxx Euro Senior CDS index in March and June 2009, respectively. The market perception of French banks as being less risky than their peers, even for the lower class of debt, may indicate that markets place a premium on national champions: Figure 12.

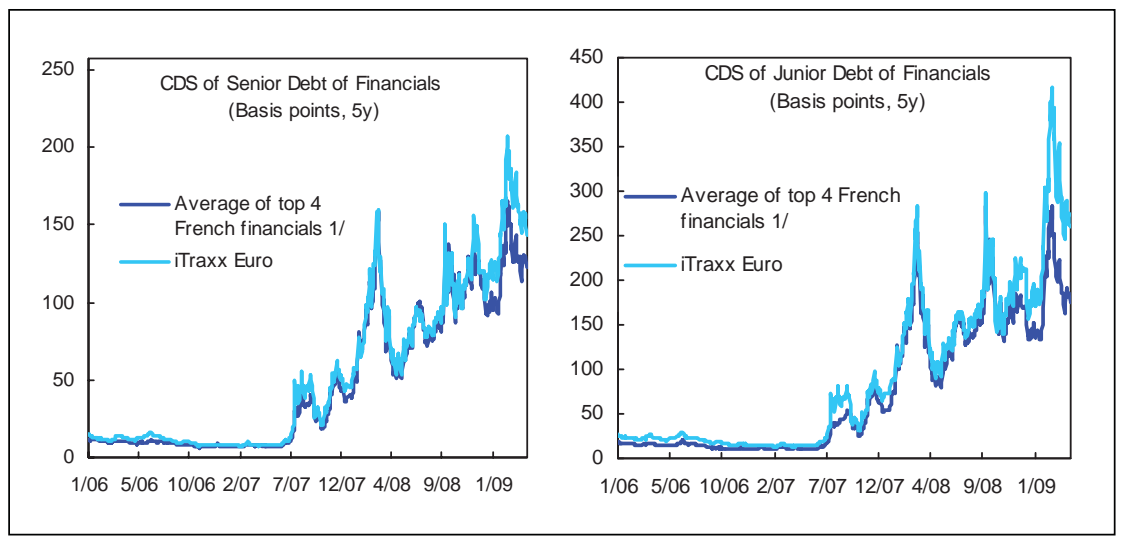

Figure 12: CD spreads of French banks 
Xiao: French Banks

\section{An Event Study of the French Banking Sector}

Before the deepening of the crisis in September 2008, the French government focused on increasing the efficiency and competitiveness of the financial sector domestically and advocated regulatory and supervisory reforms internationally. In particular, to liberalize and reform the financial sector, the government rolled out a flurry of measures under the Paris-Place Financière initiative and the Loi de Modernisation de l'Économie (LME). In the aftermath of the trading fraud at Sociétié Générale (SG), the government took actions to strengthen internal controls and operation risk management. During the 2008 French Presidency of the EU, it proposed thirty recommendations for Europe to combat the crisis.

The bankruptcy of Lehman Brothers intensified the crisis and fuelled the worst bout of financial contagion since WWII. Concerns about exposures to Lehman sparked massive turmoil in global financial markets with the freezing up of interbank, senior unsecured, covered bond and securitization markets. The financial shock in the US reverberated internationally, fuelled the global "flightto-quality," and resulted in surging spreads, collapsing equity prices, and spiking volatility.

The deepening of the crisis prompted large-scale sovereign interventions. Governments around the world took unprecedented support measures to recapitalize banks and unfreeze credit. Global government measures included recapitalization, guarantees, deposit insurance, asset swaps, asset purchases, as well as direct lending and crisis liquidity facilities. Measures in some countries came with strings attached such as conditions on dividends, salary restrictions, lending rules, code of ethics, and government appointed Board members.

As part of the global actions, the French government created two separate agencies to recapitalize banks and provide government guarantees for bank refinancing. Recapitalization was handled by the Société de Prise de Participations de l'État (SPPE), a fully state-owned agency. Refinancing operations were undertaken by the Société de Financement de l'Économie Française (SFEF), owned jointly by the French state (34 percent) and seven leading French banks (66 percent).

SPPE provided solvency support through the availability of Tier 1 capital instruments. It earmarked $€ 40$ bn of funds. In addition to the injection to Dexia along with other governments, $€ 10.5 \mathrm{bn}$ of the first tranche in the form of deeply subordinated debt securities were injected into six banks, boosting their Tier 1 ratios by about 50 bps. SPPE also supported the merger between GCE and GBP with an additional $€ 3 \mathrm{bn}$. The second tranche in the same amount to the same banks was announced, but has not been taken by all the banks yet.

There are several improvements to the new recapitalization scheme over the original one. For example, banks are given the option of issuing preference shares. Preference shares are new core Tier 1 instruments established by the French law. They have the following characteristics: non-cumulative dividend, 
no voting rights, non-convertible, preferential but capped remuneration, limited dilution, and loss-absorbing capacity. The new scheme also offers incentives for banks to buy back securities as the redemption amount would increase over time.

SFEF provided liquidity support through the provision of governmentguaranteed refinancing. It raised market financing by issuing state-guaranteed bonds, the proceeds of which were then used to on-lend to banks in proportion to the market share of each bank in terms of customer loans and assets for a period of one to five years. SFEF issued up to $€ 265 \mathrm{bn}$ of guaranteed term debt (maximum maturity five years), which enjoyed 'AAA' rating as the French government. Debt had to be issued before the end of 2009. Before the creation of the SFEF, the government also issued guarantees on Dexia's obligations (a maximum of $€ 55 \mathrm{bn}$ ) along with the rescue package arranged for the bank with other governments.

SFEF proved to be popular with investors as reflected in the very tight spreads of its bonds. Its issuance, second only to the U.S. and about one third denominated in U.S. dollars, represented 20 percent of the global issuance of government guaranteed bonds. Its ability to attract a wide range of investors from various market segments may result from its skillful set-up. By pooling liquidity, the agency enhanced the visibility and reduced the liquidity premium of its bonds. In addition, by construction, investors are not exposed to bank risks. The guarantor, the French government, is perceived to be capable of standing behind its promises. With the recent market improvement, French banks have tapped markets by issuing bonds without government guarantees.

There have been several theoretical studies of best government support schemes, but very few empirical studies. The crisis provides good natural experiments of various government support schemes, but there seems to be only one empirical study by Veronesi \& Zingles (2008) to examine the impact of the U.S. plan. To bridge this gap in the literature, this paper uses a similar method to analyse the French plan. The event window is between October 10 and October 14 in 2008, one day before and after the announcement of the French schemes on October 13, which was also the day when the U.S. government announced its revised Paulson plan and the U.K. government announced its own schemes.

The study aims to explore the impact of the French financial sector support plan by combining both the balance sheet and the market information. Specifically, it intends to: (a) the market impact on debt using senior and subordinated CDS spreads and linking these to the maturity structure of the bank debt, (b) gauge the market impact on equity using capital asset pricing model (CAPM), (c) take into account other events happening at the same time by measuring the relative impact besides the gross impact, and (d) reverse engineer the Black-Scholes-Merton model, as in Xiao (2008), to measure the proportion of equity injection transferred to debt holders.

Following Veronesi \& Zingles (2008), the impact on debt is calculated as follows: 
1. The default probability from the CDS (RR is recovery rate) is backed out.

$$
D P=\frac{C D S / 10000}{1-R R}
$$

2. The gross impact on debt is equal to the difference between the present value of debt before the plan and after the plan ( $r f$ is the risk-free rate, $b$ and a indicate before and after, respectively).

$$
\Delta P V=\sum_{t=0}^{T} \frac{\left(1-D P_{b}\right)^{t} \frac{C D S_{b}}{10000} * D_{t}}{(1+r f)^{t}}-\sum_{t=0}^{T} \frac{\left(1-D P_{a}\right)^{t} \frac{C D S_{a}}{10000} * D_{t}}{(1+r f)^{t}}
$$

3. To control other things happening at the same time, an adjusted impact is measured by subtracting debt changes in Scor Group, a reinsurance firm not receiving government money but experiencing narrowing spreads.

$$
\text { Adjusted } \triangle P V=\Delta P V-P V_{b} \times \frac{\Delta P V^{s c}}{P V_{b}^{s c}}
$$

The results show that the French support plan drove down banks' credit risk significantly: see Figure 13. The debt value of banks appreciated across the board after the announcement of the plan, with the gross appreciation ranging from 21 percent to 38 percent. As expected, taking into account other events happening at the same time lowering the impact, the positive effects of a value increase of at least 9 percent were still pronounced. In addition, subordinated debt benefited more than senior debt. On average, the value of the banks' subordinated debt went up by 35 percent on gross terms and by 25 percent on adjusted terms, while the value of the banks' senior debt went up by 26 percent and 14 percent, respectively.
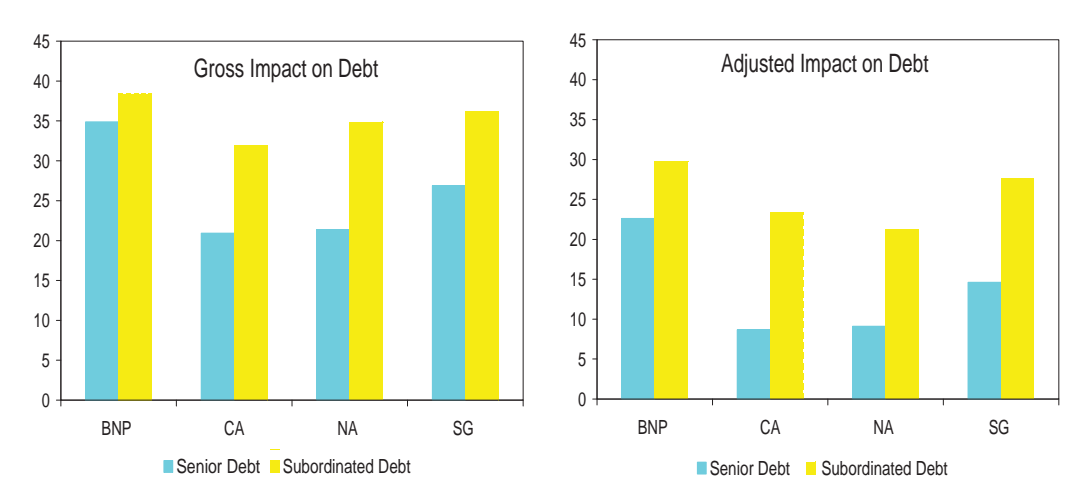

Figure 13: Impact on debt of French banks 
The impact on stock values is calculated as follows. The gross impact is measured by raw stock returns and the adjusted impact is measured by using abnormal returns from the CAPM. Beta is estimated from daily stock prices during the period 1/1/07-10/09/08. Both market benchmarks, CAC40 and $\mathrm{SBF} 250$, are used. Adjustments are done with beta equal to one and the estimated betas.

The results show that the plan had a mixed impact on equity: Figure 14. The gross impact was positive, with the equity value of the banks experiencing a modest increase of 2-7. However, the adjusted impact was negative across the board, regardless of the benchmarks and the beta estimation methods used. The loss of the equity value of the banks ranged from one to 23 percent. With the exception of one bank, the estimated betas produced larger equity value reduction than assuming betas equal to one. The different impact on debt and equity suggests the possibility of equity injections being transferred to debt, as analysed in Myers (1977).



Figure 14: Impact on equity of French banks

To measure the proportion of equity injections into debt, the BlackScholes-Merton model is reverse engineered. ${ }^{2}$ In the Black-Scholes-Merton model, asset value follows a geometric Brownian motion:

$$
\mathrm{dA} / \mathrm{A}=\mu_{\mathrm{A}} \mathrm{dt}+\sigma_{\mathrm{A}} \mathrm{dw}
$$

Equity is a call option and debt is a put option on bank assets. Specifically,

$$
\begin{aligned}
& E=\max (A-D B, 0)=\int_{D B}^{\infty} e^{-r T} E(A-D B) f(A) d A \\
& D=D B-\max (D B-A, 0)=\int_{D B}^{\infty} e^{-r T} D(A-D B) f(A) d A
\end{aligned}
$$

where

$\mathrm{E}$ is the market value of equity,

A is bank assets,

$\mathrm{D}$ is the market value of debt,

${ }^{2}$ For details, see Xiao (2008). 
DB is the distress barrier,

$\mu_{A}$ is the expected rate of return of assets,

$\mathrm{T}$ is the time to maturity on debt in years, $\sigma_{\mathrm{A}}$ is the standard deviation of assets,

$\mathrm{dw}$ is the Weiner process, and

$\mathrm{f}(\mathrm{A})$ is the asset distribution function.

To obtain the share of equity injections into debt, the following procedure is followed: (a) Calibrating the Black-Scholes-Merton model to market data of bank equity and volatility, (b) backing out the implied value and volatility of bank assets, (c) calculating ex-ante the market value of bank bonds and equities after the announcement of the plan, and (d) determining the share of equity injection into debt by the value difference between the pre- and post-plan market values relative to capital injections.

The results demonstrate that the share of transfer varies with the riskiness of banks. For the three largest French banks, the proportion of the transfer ranges from 13 to 56 percent. Moreover, the transfer dovetails with the credit risk of banks measured by the average of the CDS spreads of the banks' senior and subordinated debt. The riskier the debt, the higher is the share of capital injections into debt. It indicates that capital injections may benefit debt holders at the expense of shareholders, arguing for the necessity of injections by the government.

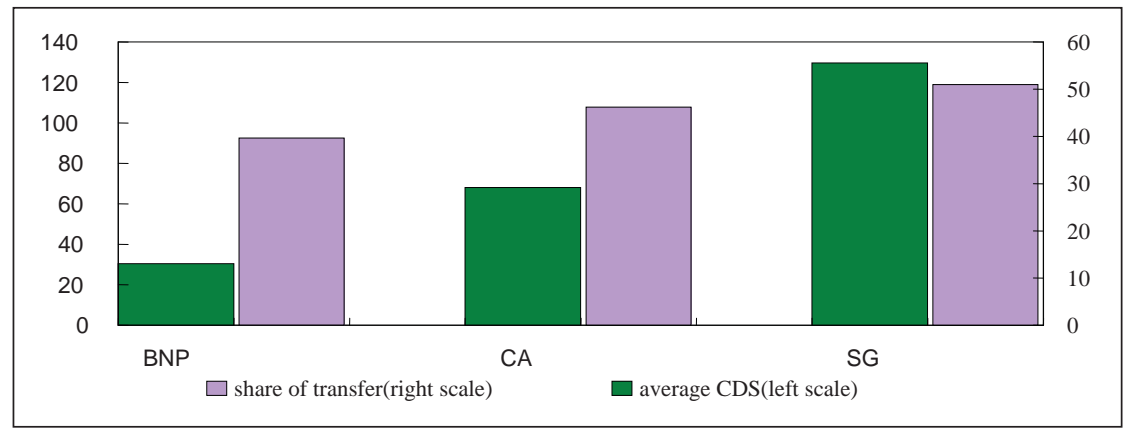

Figure 15: Share of capital injections in French banks

\section{Conclusion}

French banks have demonstrated relative resilience to the global financial crisis so far. The global crisis has put the banks to an unprecedented test and they were not immune to the severe fallout of the crisis. However, the banking model featuring diversification in business, funding, and geography has helped to contain the risk at a manageable level. In addition, benefiting from the comprehensive supervision, proactive regulation, and timely informationsharing among regulatory authorities, the banks enjoyed better initial conditions and have withstood the crisis thus far relatively well. 
Government measures are necessary and beneficial, but challenges still lie ahead. Recapitalization and refinancing measures have helped stabilize the system by reducing the risk and decreasing the financing cost considerably. Going forward, banks' earnings and profitability may continue to be under pressure with subdued CIB activities, potential losses and writedowns from risky assets, the still low interest margins, as well as the rising counterparty risk and the cost of risk. With the global crisis still unfolding and the international debate on capital adequacy still evolving, the impact of the banks' reduced comparative advantage in capital buffers remains to be seen. Rising to the challenge would call for continued vigilance and enhanced risk management.

Author information: Yingbin Xiao, Ph.D., is a senior economist of the International Monetary Fund, Washington DC. Dr. Xiao would like to thank Erik De Vrijer, Ann-Marie Gulde-Wolf, Danièle Nouy, Muriel Tiesset, an anonymous referee, and participants at the French Ministry of Economy, Finance, and Industry in Paris and the American Midwest Finance Association 2010 Conference in Las Vegas for helpful comments and suggestions. Assistance from Anastasia Guscina and Judith Rey are also acknowledged. The views expressed in this paper are those of the author and do not necessarily represent those of the IMF or IMF policy. Contact email: yxiao2@imf.org.

\section{References}

BIS. (2004). BCBS Compendium of Documents - Volume II: Advanced supervisory methods, Basel.

Black, Fischer \& Myron S. Scholes. (1973). The pricing of options and corporate liabilities. Journal of Political Economy, 81, 637-654.

Choulet, \& Céline. (2009). Banques européennes: Les plans de soutien à l'épreuve de la recession. Conjoncture 51, BNP Paribas.

Commission Bancaire. (2009). Rapport de la Commission bancaire pour l'année 2008. Paris.

Federal Reserve. (2009). The supervisory capital assessment program: Design and implementation. Federal Reserve: Washington DC.

FSA. (2009). The Turner Review. Financial Services Authority: London.

Gapen, Michael, T., Dale, F. Gray, Cheng Hoon Lim \& Yingbin Xiao. (2005). The contingent claims approach to corporate vulnerability analysis: Estimating default risk and economy-wide risk transfer. In Corporate restructuring: Lessons from experience, Michael Pomerleano and William Shaw (Eds). World Bank.

Gapen, Michael, T., Dale, F. Gray, Cheng Hoon Lim \& Yingbin Xiao. (2008), Measuring and analyzing sovereign risk with contingent claims. IMF Staff Papers, 55, 109-148.

IMF. (2009). Global financial stability report 04/09 (Washington: International Monetary Fund). 
Lagarde, \& Christine. (2008). Le plan français pour assurer le financement de l'économie et restaurer la confiance. Communiqué de presse du Conseil des Ministres, Paris.

Merton, \& Robert, C. (1973). Theory of rational option pricing. The Bell Journal of Economics and Management Science, 4, 141-183.

Merton, \& Robert, C. (1974). On the pricing of corporate debt: The risk structure of interest rates. The Journal of Finance, 29, 449-470.

Merton, \& Robert, C. (1977). An analytic derivation of the cost of loan guarantees and deposit insurance: An application of modern option pricing theory. Journal of Banking \& Finance, 1, 3-11.

Myers, S. C. (1977). Determinants of corporate borrowing. Journal of Financial Economics, 5, 147-175.

Noyer, Christian, \& Nouy Danièle. (2009). Audition devant la commission des finances du Sénat Comptes Rendus De La Commission Des Finances, Paris.

Ricol, \& Rene. (2008). Rapport sur la crise financière - Mission confiée par le Président de la République dans le contexte de la Présidence française de l'Union européenne 2008. Paris.

Veronesi, Pietro, \& Luigi Zingles. (2008). Paulson's gift. Mimeo: University of Chicago.

Yingbin Xiao. (2008). Financing and risks of French firms. Sosial Science Research Network Working Paper No. 1435088. Available at SSRN: http://ssrn. com/abstract=1435088. 